\title{
Effects of bio-optical factors on the attenuation of ultraviolet and photosynthetically available radiation in the North Water Polynya, northern Baffin Bay: ecological implications
}

\author{
Christophe Vasseur ${ }^{1, *}$, Behzad Mostajir ${ }^{2}$, Christian Nozais $^{1}{ }^{1}$ Michel Denis ${ }^{3}$, \\ Éric Fouilland ${ }^{4}$, Bert Klein ${ }^{5}$, Serge Demers ${ }^{1}$
}

${ }^{1}$ Institut des sciences de la mer de Rimouski, Université du Québec à Rimouski, 310 allée des Ursulines, Rimouski, Québec G5L 3A1, Canada

${ }^{2}$ Ecosystèmes lagunaires, CNRS, UMR 5119, Université Montpellier II, CP 093, Place Bataillon, 34095 Montpellier cedex 5, France

${ }^{3}$ Centre d'Océanologie de Marseille, Université de la Méditerranée, Laboratoire d'Océanographie et de Biogéochimie, CNRS UMR 6535, Parc Scientifique et Technologique de Luminy, Case 901, 13288 Marseille cedex 09, France

${ }^{4}$ The Scottish Association for Marine Sciences (SAMS), Dunstaffnage Marine Laboratory, Dunbeg, Oban PA37 1QA, Scotland

${ }^{5}$ Département de biologie, Université Laval, 2503 des Hospitalières, Sillery, Québec G1T 1V6, Canada

\begin{abstract}
Recently, the Arctic has experienced a recurrent springtime thinning of the stratospheric ozone layer resulting in increasing ultraviolet-B radiation (UVBR, 280 to $320 \mathrm{~nm}$ ). However, little is known about the effect of such UVBR enhancement on the Arctic ecosystem. In springsummer 1998 and fall 1999, 40 stations were investigated in the North Water Polynya (NOW), High Arctic. In the course of this study, 3 periods (pre-bloom, bloom and post-bloom) were distinguished based on chlorophyll a ( $\mathrm{chl}$ a) concentrations. The attenuation of ultraviolet radiation (UVR) and photosynthetically available radiation (PAR) are reported here. Bio-optical factors, namely particulate organic carbon (POC), dissolved organic carbon (DOC) and chl a concentrations were related to the attenuation coefficient, $K_{d}(\lambda)$, of both UVR and PAR. During the pre-bloom period (9 April to 12 May 1998), all bio-optical factors except chl a concentrations were unrelated to $K_{d}(\lambda)$. However, the absorption of colored dissolved organic matter might prevail. During the bloom period (15 May to 29 June 1998), both chl $a$ and POC were strongly correlated to $K_{d}(\lambda)$. During the post-bloom period (27 August to 25 September 1999), POC contributed from 57 to $83 \%$ of the $K_{d}(\lambda)$. Under stratification conditions, an inverse relationship was observed in the UVR and PAR ranges, between $K_{d}(\lambda)$ and the depth of the subsurface chlorophyll maximum (SCM). This could be a consequence of cell migration below the penetration depth of UVR where they are protected from UVR-induced physiological damages.
\end{abstract}

KEY WORDS: UVR · PAR · NOW Polynya · Subsurface chlorophyll maximum · Bio-optical factors Resale or republication not permitted without written consent of the publisher

\section{INTRODUCTION}

Since the early 1990s, an annual persistent thinning of the stratospheric ozone layer has been evidenced over the Antarctic (Farman et al. 1985, Solomon 1990, Hofmann \& Deshler 1991), Arctic and temperate re- gions (Chipperfield 1991, Rex et al. 1997, Shindell et al. 1998). It is well established that a reduction of the thickness in the stratospheric ozone layer (ozone hole) leads to an increase in ultraviolet-B radiation (UVBR, 280 to $320 \mathrm{~nm}$ ) reaching the Earth's surface. In the Northern Hemisphere, the decrease in the ozone layer 
has been related to the global warming of the lower atmosphere (Ramanathan 1988, Shindell et al. 1998). Indeed, models based on the greenhouse theory of climate change have shown that an increase of greenhouse gas concentrations would result in a cooler upper stratosphere (Ramanathan 1988, Shindell et al. 1998), enhancing the destruction of the ozone layer by chlorofluorocarbons (CFCs). During spring 1997, Tarasick \& Fioletov (1997) measured a $45 \%$ decrease of the thickness of the Arctic ozone layer, compared with its natural value. Models have predicted that a similar decrease could occur in the Arctic and Antarctic in the course of the 21th century (Austin et al. 1992).

UVBR is known to penetrate significant depths of the euphotic layer (Jokiel \& York 1984, Boelen et al. 1999). An increasing number of studies have reported impacts of UVBR on various biological components of marine planktonic communities. For instance, UVBR effects have been reported for bacteria (Herndl et al. 1993), phytoplankton (Ferreyra et al. 1997, Fauchot et al. 2000), protozoans (Wickham \& Carstens 1998, Chatila et al. 1999, Mostajir et al. 1999) metazoans and fishes (Rodriguez et al. 2000, Zagarese \& Williamson 2000).

Compared with Antarctic regions, little is known about the impact of a decreasing stratospheric ozone layer in Arctic regions, and particularly in polynyas. Polynyas are large areas of open water (or thin icecover) surrounded by ice occurring in the Arctic, the Southern Ocean and adjacent seas during most of the year (Muench 1971, Lewis et al. 1996). Because they may generally remain open during winter or become ice-free early in spring, polynyas are focal points for the early and intense production of phytoplankton (Lewis et al. 1996). Accordingly, polynyas have been compared to oases in terrestrial deserts (Struzik 1989). The recurring North Water Polynya (NOW) in Smith Sound and northwestern Baffin Bay, the largest in the Canadian Arctic (approximately $200 \mathrm{~km}$ wide), is ice covered during the coldest months but can have some open water in early spring (Stirling 1997). The NOW is considered to be one of the most productive areas north of the Arctic Circle (Lewis et al. 1996, Klein et al. 2002, Tremblay et al. 2002).

When assessing the impact of ultraviolet radiation (UVR, 280 to $400 \mathrm{~nm}$ ) on a natural planktonic community, it is worth measuring the depth of UVR penetration into the water column. Most of the studies reporting such measurements in Arctic regions were restricted to freshwater lakes (Laurion et al. 1997, Markager \& Vincent 2000, Belzile et al. 2001). So far, there is only one published study on the UV attenuation by first-year ice in Arctic marine waters and more specifically, in the NOW during late spring (Belzile et al. 2000). The purpose of the present investigation is: (1) to analyze the variations in the penetration of solar radiation in the
NOW marine waters; (2) to relate these variations to biooptical factors, i.e. mean integrated chlorophyll a (chl a), particulate organic carbon (POC) and dissolved organic carbon (DOC) concentrations over the euphotic layer; and (3) to assess the influence of UVR penetration on the depth of the subsurface chl a maximum (SCM).

\section{MATERIALS AND METHODS}

Study area. The present study was conducted in the NOW, northern Baffin Bay, from 9 April to 29 June 1998 (NOW98) and from 27 August to 25 September 1999 (NOW99), onboard the icebreaker CCGS (Canadian Coast Guard Ship) 'Pierre Radisson'. A total of 40 stations were sampled (Fig. 1).

Biological measurements and associated calculations. To achieve comparisons with the diffuse attenuation coefficient in the water column, water samples for analyses of chl $a$, POC and DOC were collected at 7 optical depths, according to the work of Sommaruga \& Psenner (1997), with either 10 l BOT (Brooke Ocean Technology) bottles (June 1998) or Niskin bottles, using a rosette system (General Oceanics) equipped with a CTD (ICTD, Falmouth Scientific). As reported by Mei et al. (2002), the 7 sampling depths were determined as percentage of incident light $(100,45,30,2010,1$ and $0.1 \%$ of the surface photosynthetically available radiation [PAR, 400 to $700 \mathrm{~nm}$ ] which corresponded to depths in the range of 0 to $106 \mathrm{~m}$ ). Chl $a$, POC and DOC values reported here are average concentrations over the euphotic layer (above $1 \%$ light depth).

Chl a concentrations were determined fluorometrically on aliquots of 0.1 to 0.51 of seawater samples filtered onto Whatman GF/F filters (Klein et al. 2002). Briefly, chl a concentrations were calculated using the equations of Holm-Hansen et al. (1965) after measuring fluorescence with a 10-005R Turner Designs fluorometer, following a $24 \mathrm{~h}$ extraction in $90 \%$ acetone at $4{ }^{\circ} \mathrm{C}$, without grinding (Parsons et al. 1984). The depth of the SCM was visually determined using the vertical profiles of chl a obtained from each station.

To determine POC concentrations, 0.25 to 21 of seawater samples were filtered onto precombusted $21 \mathrm{~mm}$ Whatman GF/F filters following the protocol of Knap et al. (1996). During the 1998 cruise, after drying for $24 \mathrm{~h}$ at $60^{\circ} \mathrm{C}$, the filters were stored in sealed sterile petri dishes until analysis, while during the 1999 cruise, the filters were stored frozen at $-80^{\circ} \mathrm{C}$ and dried just before analyses on a Perkin Elmer $2400 \mathrm{CHN}$ analyzer (Miller et al. 2002).

DOC samples were collected in acid-cleaned, combusted glass bottles with acid-cleaned teflon-lined caps. They were stored at $4^{\circ} \mathrm{C}$ with phosphoric acid $(0.1 \mathrm{ml}$ per $60 \mathrm{ml}$ sample, $14.7 \mathrm{M}$ ) for later analysis by 
high temperature catalytic oxidation (Miller et al. 2002).

Hydrographic measurements $\left(Z_{\mathrm{m}}\right)$. Values of salinity (S) were recorded with a Guildline AutoSal salinometer (Bâcle et al. 2002). Temperature $(\mathrm{T})$ and density $\left(\sigma_{t}\right)$ were computed following the algorithms from UNESCO (1983). The mixed layer depth $\left(Z_{\mathrm{m}}\right)$ was determined by Tremblay et al. (2002) according to the method of Schneider \& Müller (1990). Hydrographic data were acquired with a CTD.

Light measurements. Vertical light profiles were acquired with a PUV-542T/GUV-541 radiometer (Biospherical Instruments) that provides cosine-corrected downwelling irradiance in 5 discrete channels in the UVR range (305, $313,320,340$ and $380 \mathrm{~nm}$ ) and 1 for the PAR (400 to $700 \mathrm{~nm}$ ). Data were recorded on a portable computer using PRR software while the radiometer was slowly lowered through the water column $\left(1 \mathrm{~m} \mathrm{~s}^{-1}\right)$. Average dark values for downwelling irradiance were measured in the field using light-tight neoprene caps as according to Kirk (1994). To identify different water masses, the attenuation coefficient, $K_{d}(\lambda)\left(\mathrm{m}^{-1}\right)$, was determined at each channel using the relationship:

$$
K_{d}(\lambda)=\ln \left[\operatorname{Ed} 0^{-}(\lambda) / \operatorname{Ed} z(\lambda)\right] / \Delta z
$$

where $\operatorname{Ed} 0^{-}(\lambda)$ and $\operatorname{Ed} z(\lambda)$ are the downwelling irradiance just below the water surface and at

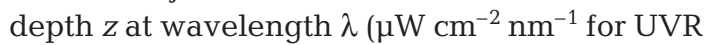
and $\mu \mathrm{E} \mathrm{m}^{-2} \mathrm{~s}^{-1}$ for PAR), respectively. During the light profiling, variations in above sea incident irradiance were assessed with a GUV-541 radiometer (Biospherical Instruments). The GUV radiometer was located on top of the wheelhouse to avoid any shadow effect. The mean irradiance in the euphotic zone was calculated from Eq. (2) (MacIntyre \& Cullen 1996):

$$
\mathrm{I}(\lambda)=\left[\operatorname{Ed} 0^{-}(\lambda) / K_{d}(\lambda) Z_{\text {eu }}\right]\left[1-\exp \left(-K_{d}(\lambda) Z_{\text {eu }}\right]\right.
$$

where $Z_{\mathrm{eu}}(\mathrm{m})$ is the depth of the euphotic zone, and $\operatorname{Ed} 0^{-}(\lambda)$ and $K_{d}(\lambda)$ are as defined in Eq. (1).

Statistical analyses. During both the whole and postbloom periods, sufficient data were obtained and stepwise linear regression models between $K_{d}(\lambda)$ and biooptical factors (POC, DOC and chl a concentrations) were calculated using SPSS 11 software to determine the most influential factor on the light attenuation. A variable was entered into the model if the significance level of its $F$-value was less than 0.05 and was removed if the significance level was greater. SPSS 11 was also used to compute Pearson correlation coefficients between $K_{d}(\lambda)$ and the bio-optical factors for both the

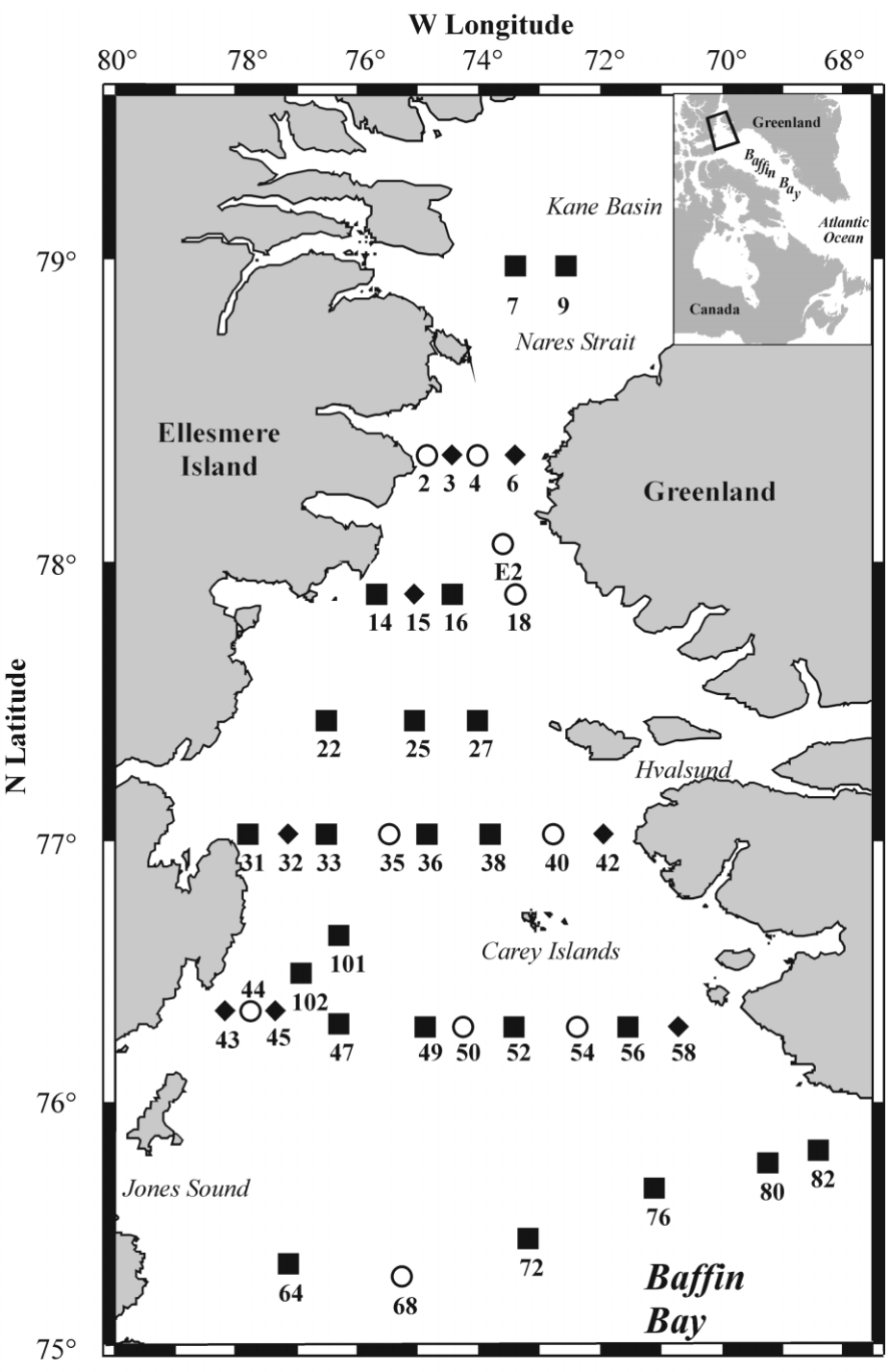

Fig. 1. Location of stations sampled in the North Water, High Arctic, in $1998(\square), 1999(\diamond)$ and in both years (O)

pre-bloom and bloom periods when too few data were available to compute stepwise linear regression models. Spearman correlation coefficients were calculated (SPSS 11) between the depth of the SCM and chl a concentrations for the bloom and post-bloom periods when $Z_{\mathrm{m}}<15 \mathrm{~m}$.

\section{RESULTS}

\section{Spatio-temporal variations of chl $a$, POC and DOC concentrations in the NOW}

Based on phytoplankton chl a concentrations measured in the NOW (see stations in Fig. 1), distinct periods have been identified by Mei et al. (2002) as: (1) the 


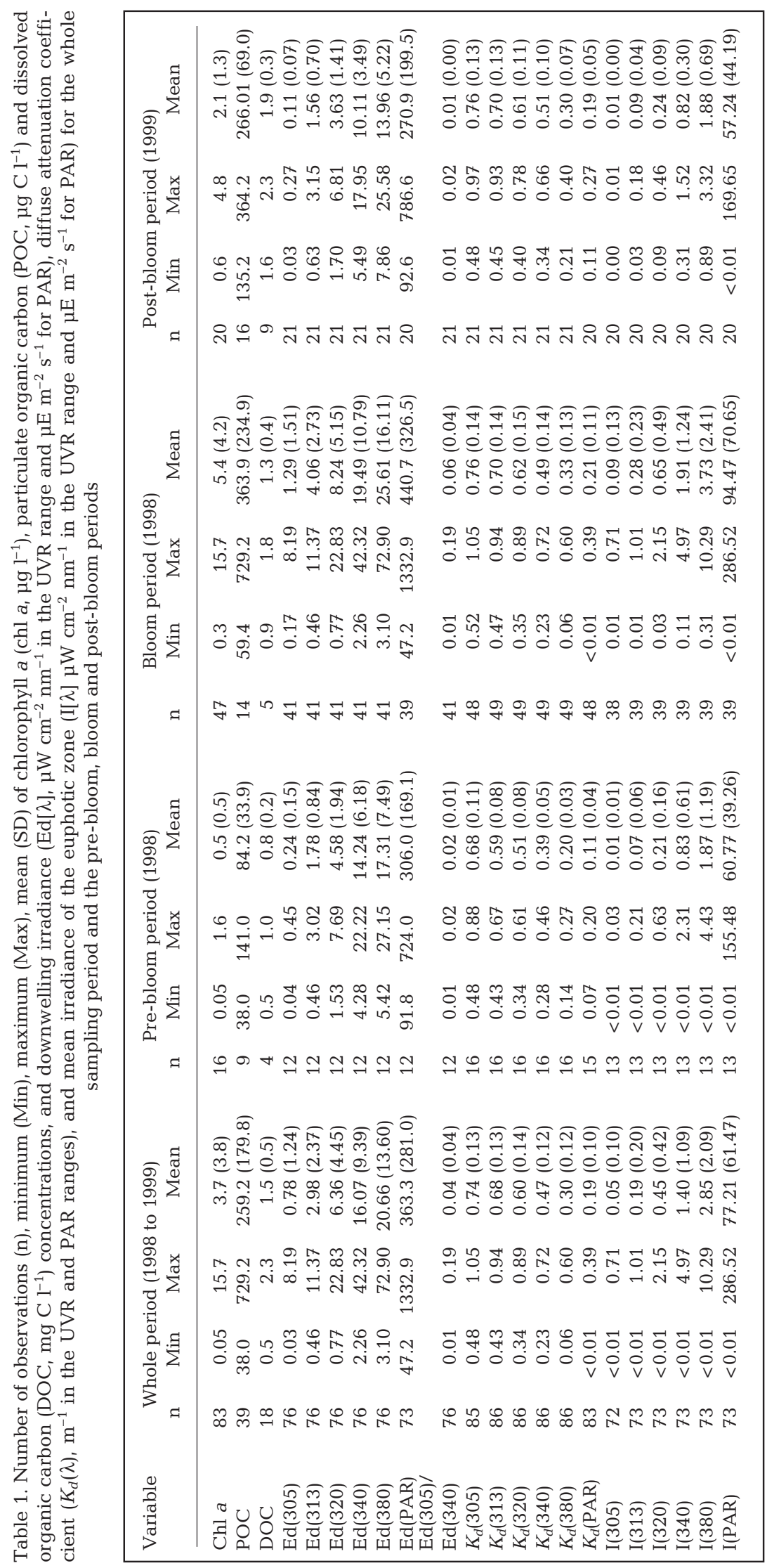

pre-bloom with chl $a<1 \mu \mathrm{g} \mathrm{l}^{-1}$ from 9 April to 12 May 1998; (2) the bloom period with chl $a$ ranging from 0.3 to $<16 \mu \mathrm{g} \mathrm{l}^{-1}$ from 15 May to 29 June 1998; and (3) the post-bloom period with chl a ranging from 0.6 to $<4.8 \mu \mathrm{g} \mathrm{l}^{-1}$ from 27 August to 25 September 1999 (Table 1). Chl a concentrations exhibited a strong variability over the whole sampling period, ranging from 0.05 to $15.7 \mathrm{gg} \mathrm{l}^{-1}$

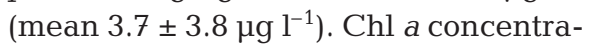
tions remained relatively low during the pre-bloom period, averaging $0.5 \pm$ $0.5 \mu \mathrm{g} \mathrm{l}^{-1}$ and then increased significantly during the bloom period, reaching $15.7 \mathrm{\mu g} \mathrm{l}^{-1}$ (Stn 54, 26 May 1998) and averaging $5.4 \pm 4.2 \mu \mathrm{g} \mathrm{l}^{-1}$. Lastly, chl a concentrations decreased during the post-bloom period, averaging $2.1 \pm$ $1.3{\mu \mathrm{gl}^{-1}}^{-1}$ (Table 1).

As shown in Table 1, POC concentrations in the NOW (Fig. 1) varied between 38.0 and $729.2 \mathrm{\mu g} \mathrm{C} \mathrm{l}^{-1}$ (mean $259.2 \pm 179.8 \mu \mathrm{g} \mathrm{C}^{-1}$ ) over the whole period. During the pre-bloom period, POC concentrations averaged $84.2 \pm$ $33.9 \mu \mathrm{g} \mathrm{Cl}^{-1}$. As for chl $a$, it increased in the bloom period reaching $729.2 \mu \mathrm{g} \mathrm{C}$ $\mathrm{I}^{-1}$ (Stn 31, 15 June 1998) and averaging $363.9 \pm 234.9 \mathrm{\mu g} \mathrm{C} \mathrm{l}^{-1}$. During the postbloom period, however, POC concentrations was lower, averaging $266.0 \pm$ $69.0 \mu \mathrm{g} \mathrm{Cl}^{-1}$.

Over the whole period, the DOC concentrations (Fig. 1) varied from 0.5 to $2.3 \mathrm{mg} \mathrm{Cl}^{-1}$ (mean $1.5 \pm 0.5 \mathrm{mg} \mathrm{Cl}^{-1}$ ). They exhibited a different temporal pattern than those of chl $a$ and POC. Indeed, DOC concentrations increased progressively from the pre-bloom (mean $0.8 \pm$ $0.2 \mathrm{mg} \mathrm{Cl}^{-1}$ ), to the bloom (mean $1.3 \pm$ $0.4 \mathrm{mg} \mathrm{C} \mathrm{l}^{-1}$ ) and finally to post-bloom (mean $1.9 \pm 0.3 \mathrm{mg} \mathrm{Cl}^{-1}$ ) period.

\section{Variability of UVR and PAR in the NOW}

Light irradiance measurements were performed under different meteorological conditions from clear and sunny days with calm seas to hazy and snowy days with rough seas. These large meteorological variations significantly influenced the downwelling under- 


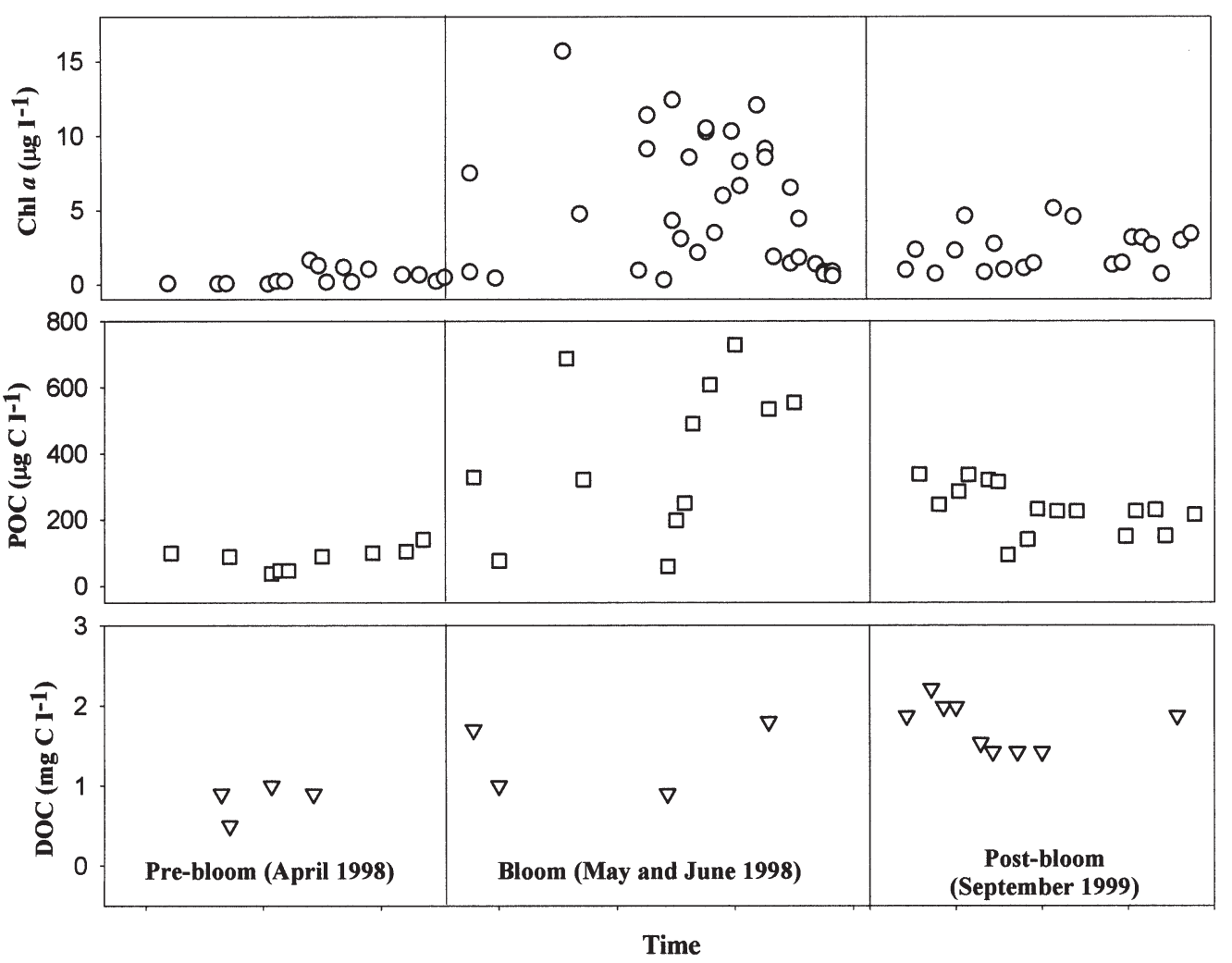

Fig. 2. Temporal variation of $\mathrm{chl} a\left(\mu \mathrm{g} \mathrm{l}^{-1}\right)$, POC $\left(\mu \mathrm{g} \mathrm{Cl}^{-1}\right)$ and DOC $\left(\mathrm{mg} \mathrm{C}^{-1}\right)$ concentrations in the NOW in 1998 and 1999

water irradiance levels just below sea surface, $\operatorname{Ed}^{-}(\lambda)$, which for PAR, 320 and $380 \mathrm{~nm}$ averaged 363 $( \pm 281) \mu \mathrm{E} \mathrm{m} \mathrm{m}^{-2} \mathrm{~s}^{-1}, 6.4( \pm 4.5)$ and $20.7( \pm 13.6) \mu \mathrm{W} \mathrm{cm}{ }^{-2}$ $\mathrm{nm}^{-1}$, respectively. During the pre-bloom, $\operatorname{Ed0}^{-}(\lambda)$ averaged $4.6( \pm 1.9)$ and $17.3( \pm 7.5) \mu \mathrm{W} \mathrm{cm}{ }^{-2} \mathrm{~nm}^{-1}$ at 320 and $380 \mathrm{~nm}$, respectively, and $306( \pm 169) \mu \mathrm{E} \mathrm{m} \mathrm{m}^{-2}$ $\mathrm{s}^{-1}$ for PAR. Mean downwelling irradiance values were higher during the bloom than during the prebloom period, reaching $8.2( \pm 5.2)$ and $25.6( \pm 16.1) \mu \mathrm{W}$ $\mathrm{cm}^{-2} \mathrm{~nm}^{-1}$ at 320 and $380 \mathrm{~nm}$, respectively, and 441 $( \pm 327) \mu \mathrm{E} \mathrm{m} \mathrm{m}^{-2} \mathrm{~s}^{-1}$ for PAR. The post-bloom period exhibited lower mean irradiance values than those recorded during the pre-bloom period. Indeed, the downwelling irradiance averaged $3.6( \pm 1.4)$ and 14.0 $( \pm 5.2) \mu \mathrm{W} \mathrm{cm} \mathrm{nm}^{-1}$ at 320 and $380 \mathrm{~nm}$, respectively, and $271( \pm 199) \mu E \mathrm{~m}^{-2} \mathrm{~s}^{-1}$ for PAR (Table 1). During the present study, the ratio Ed305/Ed340, an index of the thickness of the ozone layer (Bruce et al. 1994), averaged $0.02( \pm 0.01)$ during the pre-bloom, 0.06 $( \pm 0.04)$ during the bloom and $0.01( \pm 0.01)$ during the post-bloom period.

The averaged $K_{d}(\lambda)$ values during the whole period were $0.74( \pm 0.13), \quad 0.68( \pm 0.13), 0.60( \pm 0.14), 0.47$ $( \pm 0.12)$ and $0.30( \pm 0.12) \mathrm{m}^{-1}$ at $305,313,320,340$ and $380 \mathrm{~nm}$, respectively, and $0.19( \pm 0.10) \mathrm{m}^{-1}$ for PAR (Table 1). The lowest $K_{d}(\lambda)$ values, like $\mathrm{chl} a$, POC and
DOC concentrations (Fig. 2), were observed during the pre-bloom period, averaging $0.51( \pm 0.08)$ and 0.20 $( \pm 0.03) \mathrm{m}^{-1}$ at 320 and $380 \mathrm{~nm}$, respectively, and 0.11 $( \pm 0.04) \mathrm{m}^{-1}$ for PAR (Table 1). As for chl $a$, POC and DOC concentrations, $K_{d}(\lambda)$ values were higher during the bloom than during the pre-bloom period, averaging $0.62( \pm 0.15)$ and $0.33( \pm 0.13) \mathrm{m}^{-1}$ at 320 and $380 \mathrm{~nm}$, respectively, and $0.21( \pm 0.11) \mathrm{m}^{-1}$ for PAR (Table 1). Averaged $K_{d}(\lambda)$ values recorded during the post-bloom period were close to those measured during the bloom period with $0.61( \pm 0.11)$ and $0.30( \pm 0.07)$ $\mathrm{m}^{-1}$ at 320 and $380 \mathrm{~nm}$, respectively, and $0.19( \pm 0.05)$ $\mathrm{m}^{-1}$ for PAR (Table 1). To achieve a consistent comparison of $K_{d}(\lambda)$ values with the depths of SCM, $K_{d}(\lambda)$ values were converted according to Kirk (1994), in terms of depth of $1 \%$ surface light irradiance (Fig. 3). Over the whole period, the depth of $1 \%$ surface irradiance averaged $8.1( \pm 2.0)$ and $18.2( \pm 8.6) \mathrm{m}$ at 320 and $380 \mathrm{~nm}$, respectively, and $30.8( \pm 15.6) \mathrm{m}$ for PAR. The mean depth of $1 \%$ surface irradiance decreased from the pre-bloom to the bloom period, from $9.4( \pm 1.8)$ to $7.9( \pm 2.1) \mathrm{m}$ at $320 \mathrm{~nm}$ and from $47.5( \pm 14.0)$ to 27.4 $( \pm 15.1) \mathrm{m}$ for PAR. The average depth of $1 \%$ surface irradiance during the post-bloom period did not differ significantly from that of the bloom period, penetrating to $7.8( \pm 1.6)$ at $320 \mathrm{~nm}$ and to $26.4( \pm 8.1) \mathrm{m}$ for PAR 

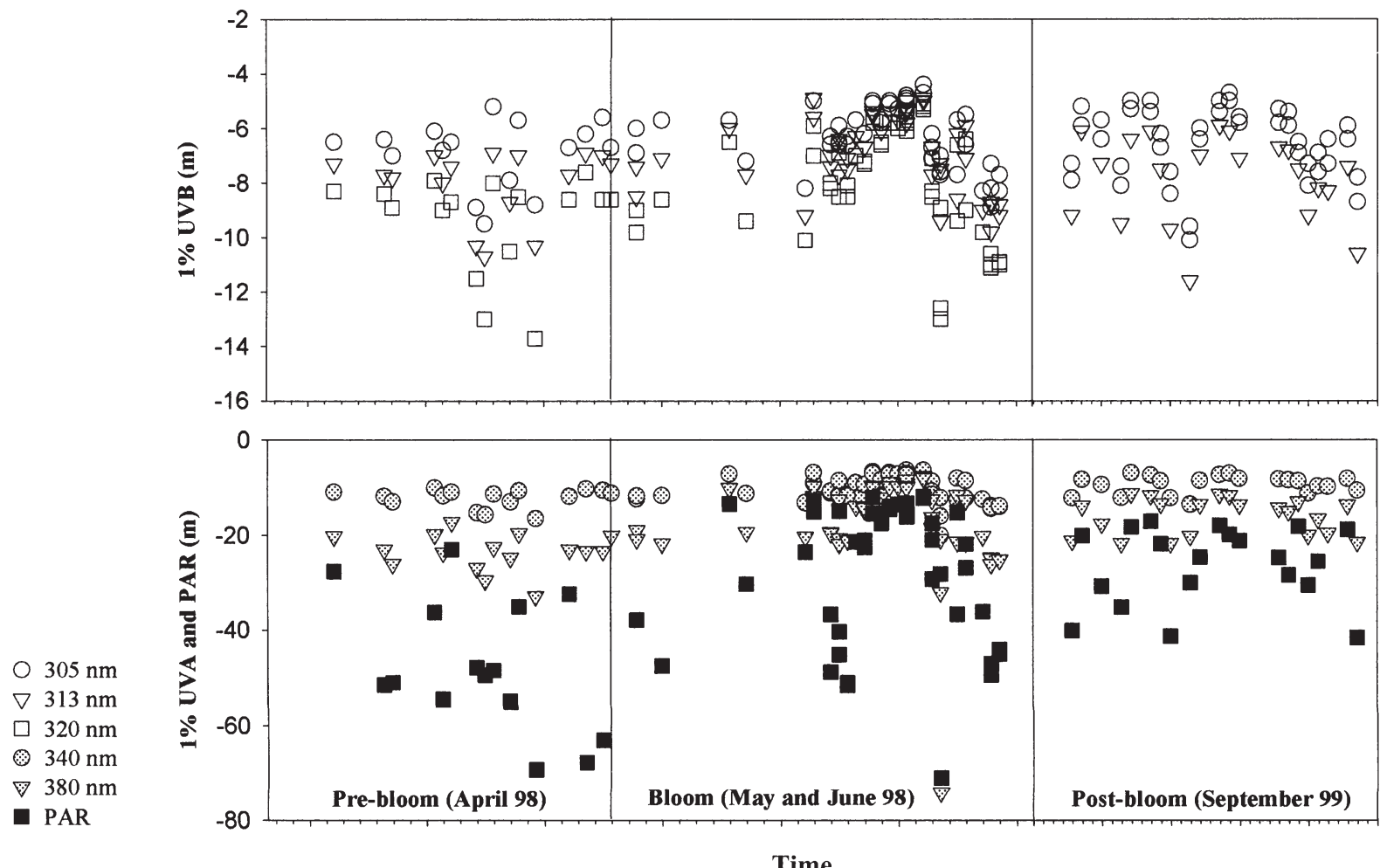

Fig. 3. Temporal variation in the $1 \%$ penetration depth of UVBR at 305,313 and $320 \mathrm{~nm}$, UVAR at 340 and $380 \mathrm{~nm}$, and PAR (400 to $700 \mathrm{~nm}$ ) in the NOW in 1998 and 1999. The $1 \%$ penetration depth has been calculated from the attenuation coefficient as according to Kirk (1994)

(Fig. 3). The mean irradiance in the euphotic zone, $\mathrm{I}(\lambda)$, defined by Eq. (2), displayed a seasonal pattern similar to that of $K_{d}(\lambda)$ (Table 1), with maximum values of 2.15 at $320 \mathrm{~nm}$ and $10.29 \mu \mathrm{W} \mathrm{cm} \mathrm{nm}^{-1}$ at $380 \mathrm{~nm}$ and $286.52 \mu \mathrm{E} \mathrm{m}^{-2} \mathrm{~s}^{-1}$ for PAR during the bloom period (Table 1).

Table 2. Stepwise linear regression modeling light attenuation and POC concentrations in the NOW during the whole sampling period and post-bloom periods. Number of observations is given in brackets. Significance levels are: ${ }^{*} 0.01<\mathrm{p} \leq$ $0.05 i^{* *} 0.001<\mathrm{p} \leq 0.01 i^{* * *} \mathrm{p} \leq 0.001$

\begin{tabular}{|c|c|c|}
\hline $\begin{array}{l}\text { Period } \\
\quad \text { Model description }\end{array}$ & $\mathrm{R}^{2}$ & $\mathrm{p}$ \\
\hline \multicolumn{3}{|l|}{ Whole $(\mathrm{n}=26)$} \\
\hline$K_{d}(340)=0.380+4.396 \times 10^{-4} \mathrm{POC}$ & 0.36 & $0.018^{*}$ \\
\hline$K_{d}(380)=0.198+4.177 \times 10^{-4} \mathrm{POC}$ & 0.60 & $<0.001^{* * *}$ \\
\hline$K_{d}(\mathrm{PAR})=0.087+4.067 \times 10^{-4} \mathrm{POC}$ & 0.79 & $<0.001^{* * *}$ \\
\hline \multicolumn{3}{|l|}{ Post-bloom (n = 12) } \\
\hline$K_{d}(305)=0.376+1.479 \times 10^{-3} \mathrm{POC}$ & 0.57 & $0.03^{*}$ \\
\hline$K_{d}(313)=0.336+1.436 \times 10^{-3} \mathrm{POC}$ & 0.60 & $0.025^{*}$ \\
\hline$K_{d}(320)=0.300+1.231 \times 10^{-3} \mathrm{POC}$ & 0.62 & $0.021^{*}$ \\
\hline$K_{d}(340)=0.208+1.193 \times 10^{-3} \mathrm{POC}$ & 0.75 & $0.006^{* *}$ \\
\hline$K_{d}(380)=0.132+7.755 \times 10^{-4} \mathrm{POC}$ & 0.82 & $0.002^{* *}$ \\
\hline$K_{d}(\mathrm{PAR})=0.052+5.744 \times 10^{-4} \mathrm{POC}$ & 0.83 & $0.002^{* *}$ \\
\hline
\end{tabular}

\section{Light attenuation by DOC, POC and chl a concentrations in the NOW}

For the whole period, the stepwise regression models showed a high contribution of POC concentration to light attenuation (Table 2). The influence of POC was obviously stronger in longer wavelengths than in the short wavelengths. The determination coefficients of the models ranged from $0.36(340 \mathrm{~nm})$ to 0.79 (PAR).

$K_{d}(\lambda)$ values were inversely correlated to chl a concentrations during the pre-bloom period (Table 3, Fig. 4). No significant relationship was found between the other bio-optical factors (POC and DOC) and the set of $K_{d}(\lambda)$. The Pearson correlation coefficient between $K_{d}(\lambda)$ and chl a ranged from -0.33 (PAR) to -0.78 (305 nm).

The bloom occurred during the ice-melt season (midMay to end of June 1998). Two stations (Stns 2 and 22; Fig. 1) out of 40 were not considered in the following analyses since they were completely covered by an icepack, unlike other stations. The occurrence of this icepack cover and low chl a concentrations $\left(\leq 0.4 \mu \mathrm{g} \mathrm{l}^{-1}\right)$ demonstrates that the bloom conditions were not yet established at these 2 stations. It is however difficult, in fact almost impossible, to present a simple map of the influence of ice at each period in the Polynya. Waters 


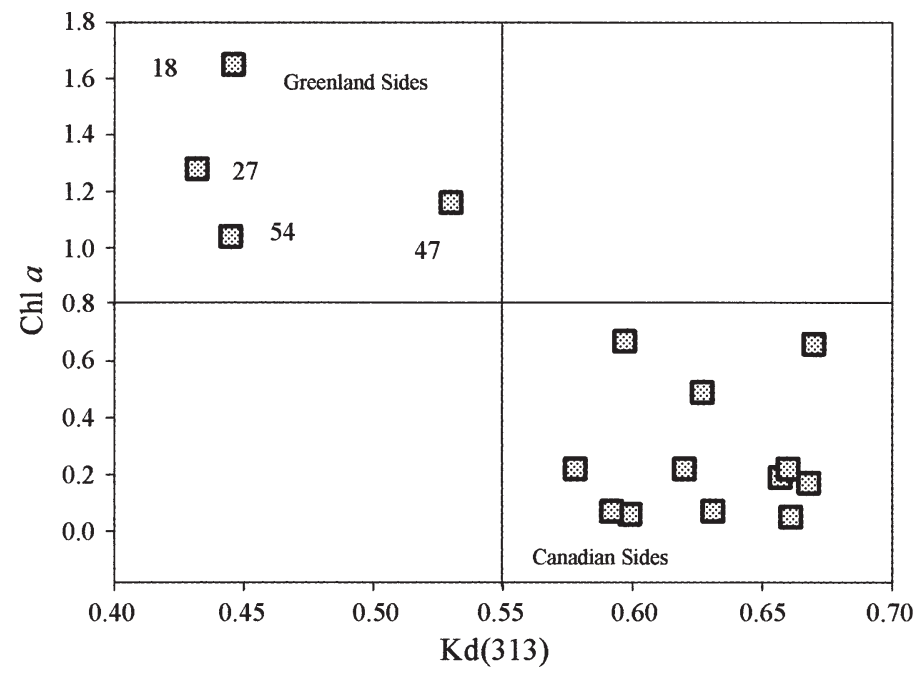

Fig. 4. Relationship between $K_{d}(\lambda)$ and chl a during the prebloom period in the North Water Polynya

along the Greenland side were mostly ice-free, while along the Canadian side, little melt-ice cover could be found at some stations. The bloom and post-bloom periods were mostly ice free. A significant increase in the concentrations of the bio-optical factors was observed during the bloom period at all sampled stations without ice-cover. Results shown in Table 3 provide evidence that both POC and chl a contributed strongly to the light attenuation in the NOW during the bloom period. For instance, the Pearson correlation coefficient for POC concentration ranged from $0.80(305 \mathrm{~nm})$ to 0.98 (PAR). The Pearson correlation coefficient for chl a ranged from $0.75(305 \mathrm{~nm})$ to 0.77 (PAR).

Table 3. Pearson correlation coefficient between $K_{d}(\lambda)$ and bio-optical factors during the pre-bloom and bloom periods. Sample size is presented in brackets. Significance levels are: ${ }^{*} 0.001<\mathrm{p} \leq 0.01$. nd: not determined

\begin{tabular}{|cccc|}
\hline $\begin{array}{c}\text { Period } \\
\text { Variable }\end{array}$ & Chl $a$ & POC & DOC \\
\hline Pre-bloom & & & \\
$K_{d}(305)$ & $-0.783^{*}(16)$ & $0.151(9)$ & $0.189(4)$ \\
$K_{d}(313)$ & $-0.803^{*}(16)$ & $-0.077(9)$ & $0.086(4)$ \\
$K_{d}(320)$ & $-0.765^{*}(16)$ & $-0.026(9)$ & $0.132(4)$ \\
$K_{d}(340)$ & $-0.719^{*}(16)$ & $-0.172(9)$ & $0.432(4)$ \\
$K_{d}(380)$ & $-0.606^{*}(16)$ & $-0.418(9)$ & $0.55(4)$ \\
$K_{d}(\mathrm{PAR})$ & $-0.333^{*}(15)$ & $-0.371(9)$ & $0.534(4)$ \\
Bloom & & & \\
$K_{d}(305)$ & $0.748^{*}(43)$ & $0.799^{*}(11)$ & nd $(2)$ \\
$K_{d}(313)$ & $0.724^{*}(44)$ & $0.874^{*}(11)$ & nd (2) \\
$K_{d}(320)$ & $0.742^{*}(44)$ & $0.875^{*}(11)$ & nd (2) \\
$K_{d}(340)$ & $0.773^{*}(44)$ & $0.956^{*}(11)$ & nd (2) \\
$K_{d}(380)$ & $0.767^{*}(44)$ & $0.979^{*}(11)$ & nd (2) \\
$K_{d}(\mathrm{PAR})$ & $0.773^{*}(44)$ & $0.983^{*}(11)$ & nd $(2)$ \\
& & & \\
\hline
\end{tabular}

During the post-bloom period, only POC was positively correlated to $K_{d}(\lambda)$, and explained from 83 to $57 \%$ of the light attenuation for PAR and $305 \mathrm{~nm}$, respectively (Table 2). Neither chl a nor DOC contributed to the stepwise linear models.

\section{Relationships between UVR penetration and depth of the SCM}

During the pre-bloom period in the ice-covered NOW, all but 1 station (Stn 54) exhibited homogeneous chl a concentration within the water column (Table 4). During the bloom period, the mean values of the depth of the SCM, the $Z_{\mathrm{m}}$ and the $Z_{\text {eu }}$ were $19.6( \pm 9.8), 15.2$ $( \pm 11.0)$ and $26.2( \pm 14.8) \mathrm{m}$, respectively (Table 4$)$. Therefore, conditions were favorable to phytoplankton development in the water column. During the postbloom period, light and mixing conditions were still favorable to phytoplankton development. During this period, 15 out of 21 stations exhibited a SCM (for examples, see Fig. 5) with a depth averaging $20.8 \pm$ $7.5 \mathrm{~m}$, while $Z_{\mathrm{m}}$ and $Z_{\text {eu }}$ averaged $13.3( \pm 5.6)$ and $26.4( \pm 8.1) \mathrm{m}$, respectively (Table 4$)$. ANOVA treatments showed a significant difference between the pre-bloom and the bloom periods $(\mathrm{p}<0.001)$ and also

Table 4. Minimum (Min), maximum (Max), mean (SD) of the depth of the subsurface chlorophyll maximum (SCM, m), mixed layer $\left(Z_{\mathrm{m}}, \mathrm{m}\right)$ and euphotic layer $\left(Z_{\mathrm{eu}}\right)$ for the whole sampling period, and during the pre-bloom, bloom and postbloom periods. For each period, $\mathrm{n}$ denotes the number of stations where the variables occur

\begin{tabular}{|lrrrl|}
\hline $\begin{array}{l}\text { Period } \\
\text { Variable }\end{array}$ & $\mathrm{n}$ & Min & Max & Mean (SD) \\
\hline Whole & & & & \\
$\quad \mathrm{SCM}$ & 50 & 3.0 & 33.0 & $19.9(9.0)$ \\
$Z_{\mathrm{m}}$ & 84 & 5.0 & 104.0 & $20.1(17.1)$ \\
$Z_{\mathrm{eu}}$ & 82 & 11.9 & 71.0 & $30.8(15.5)$ \\
Pre-bloom & & & & \\
SCM & 1 & 17.0 & 17.0 & $17(\mathrm{nd})$ \\
$Z_{\mathrm{m}}$ & 16 & 14.5 & 104.0 & $41.6(24.4)$ \\
$Z_{\mathrm{eu}}$ & 15 & 23.0 & 69.2 & $47.5(14.0)$ \\
Bloom & & & & \\
SCM & 34 & 3.0 & 33.0 & $19.6(9.8)$ \\
$Z_{\mathrm{m}}$ & 44 & 5.0 & 58.8 & $15.2(11.0)$ \\
$Z_{\mathrm{eu}}$ & 44 & 11.9 & 71.0 & $26.2(14.8)$ \\
Post-bloom & & & & \\
SCM & 15 & 6.0 & 33.0 & $20.8(7.5)$ \\
$Z_{\mathrm{m}}$ & 21 & 5.5 & 27.5 & $13.3(5.6)$ \\
$Z_{\mathrm{eu}}$ & 20 & 17.2 & 41.7 & $26.4(8.1)$ \\
$Z_{\mathrm{m}}<15 \mathrm{~m}$ & & & & \\
SCM & 34 & 4.0 & 33.0 & $18.3(8.8)$ \\
$Z_{\mathrm{m}}$ & 38 & 5.0 & 14.9 & $9.3(2.8)$ \\
$Z_{\mathrm{eu}}$ & 37 & 11.9 & 71.0 & $25.7(13.2)$ \\
& & & & \\
\hline
\end{tabular}



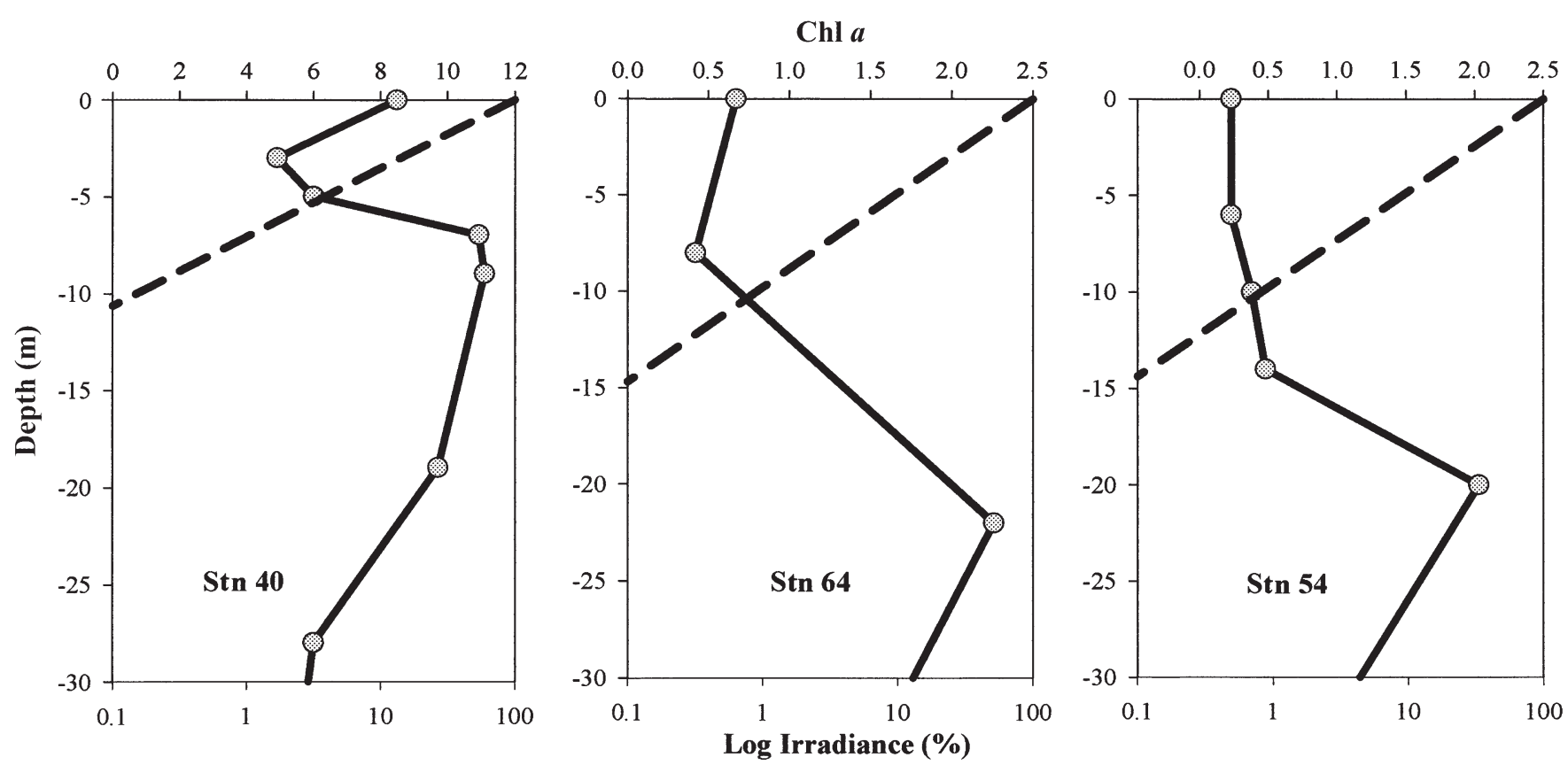

Fig. 5. Examples of vertical profiles of chl $a$ and UVR (at $320 \mathrm{~nm}$ ) at Stns 40 and 64 during the bloom and Stn 54 during the post-bloom periods, respectively, in the NOW with $Z_{\mathrm{m}}<15 \mathrm{~m}$

between the pre-bloom and the post-bloom periods $(\mathrm{p}<0.001)$. However, between the bloom and the post-bloom periods, no significant difference could be found.

Significant relationships between the $K_{d}(\lambda)$ in the UVR and PAR range and the depth of the SCM were assessed at stations with $Z_{\mathrm{m}}<15 \mathrm{~m}$, a range of depths where high irradiance conditions prevail. $Z_{\mathrm{m}}<15 \mathrm{~m}$ occurred at 25 stations sampled during the bloom period and 13 stations during the post-bloom period. Among these 38 stations, 34 exhibited a SCM (mean: $18.3 \pm 8.8 \mathrm{~m} ; 23$ cases in the bloom and 11 cases in the post-bloom period). At these 34 stations, 2 types of significant correlations were observed at all considered

Table 5. Spearman correlation coefficients between the attenuation coefficient $\left(K_{d}[\lambda] \mathrm{m}^{-1}\right.$ in the UVR and PAR ranges) and the depth of the subsurface chlorophyll maximum (SCM, m), or mean chl a concentrations over the euphotic layer (chl $a_{1} \mu \mathrm{g}$ $\mathrm{l}^{-1}$ ) for 38 stations visited during the bloom and post-bloom periods where $Z_{\mathrm{m}}<15 \mathrm{~m}$. Sample size is presented in brackets. Significance level is: ${ }^{*} 0.001<p \leq 0.01$

\begin{tabular}{|lcc|}
\hline & Chl $a$ & Depth of the SCM \\
\hline$K_{d}(305)$ & $0.727^{*}(37)$ & $-0.549^{*}(33)$ \\
$K_{d}(313)$ & $0.748^{*}(38)$ & $-0.523^{*}(34)$ \\
$K_{d}(320)$ & $0.771^{*}(38)$ & $-0.624^{*}(34)$ \\
$K_{d}(340)$ & $0.760^{*}(38)$ & $-0.636^{*}(34)$ \\
$K_{d}(380)$ & $0.819^{*}(38)$ & $-0.606^{*}(34)$ \\
$K_{d}(\mathrm{PAR})$ & $0.850^{*}(38)$ & $-0.598^{*}(34)$ \\
\hline
\end{tabular}

wavelengths. The mean chl a concentration over the euphotic layer was positively correlated to $K_{d}(\lambda)$ and explained from $73 \%(305 \mathrm{~nm})$ to $85 \%$ (PAR) of the light attenuation (Table 5 ), and $K_{d}(\lambda)$ was inversely correlated to the depth of the SCM and explained the depth of the SCM from more than $54(305 \mathrm{~nm})$ to nearly $60 \%$ (PAR; Table 5). This inverse relationship leads to a deeper SCM (mean $18.3 \pm 8.8 \mathrm{~m}$; Table 4) with a deeper penetration of UVR (mean $8.1 \pm 2.2$ and $17.7 \pm$ $11.2 \mathrm{~m}$ at 320 and $380 \mathrm{~nm}$, respectively; Fig. 3). No relationship was found between the depths of the SCM and the nitracline (data not shown).

\section{DISCUSSION}

In recent years, the Arctic ecosystem has been exposed to increasing UVBR as a consequence of the thinning of the stratospheric ozone layer (Chipperfield 1991), which is linked to global warming (Shindell et al. 1998). Little is known about the effect of such a UVBR increase on this ecosystem, particularly on polynyas, which are highly productive areas (Lewis et al. 1996). The present study was conducted in the NOW polynya in order to gain a better insight into: (1) seasonal variation (over several seasons) of light (UVR and PAR) and its attenuation by bio-optical factors (i.e. chl $a$, POC and DOC), taking into account their spatial distributions; and (2) the possible influence of UVR on the depth of the SCM. 
Three distinct periods were identified by Mei et al. (2002) in the NOW, based on the chl a concentrations: pre-bloom, bloom and post-bloom periods. The results are discussed according to these 3 defined periods.

\section{Variability of UVR and PAR in the NOW}

Whatever the wavelengths considered, the highest levels of incident irradiance occurred during the bloom period, while the lowest values occurred during the pre-bloom period (Table 1). Also, for the whole set of wavelengths, light attenuation was very similar during the bloom and post-bloom periods, and was higher than those recorded in the pre-bloom period. The bloom period had the highest average irradiance in the photic zone (Table 1). The combination of the lowest incident irradiance and light attenuation during the pre-bloom period compared with the higher values observed during the post-bloom period, yielded similar values of mean irradiance through the photic zone. In Japanese temperate coastal waters, Kuwahara et al. (2000) recorded incident irradiance at $320 \mathrm{~nm}$ from 3.0 to $23.0 \mu \mathrm{W} \mathrm{cm} \mathrm{cm}^{-1}$, overlapping the range of values (0.8 to $22.8 \mu \mathrm{W} \mathrm{cm} \mathrm{cm}^{-2} \mathrm{~nm}^{-1}$ ) observed in the present investigation. The maximum incident PAR (1600 $\mu \mathrm{E}$ $\mathrm{m}^{-2} \mathrm{~s}^{-1}$ ) reported by Kuwahara et al. (2000) is only $17 \%$ higher than the maximum PAR irradiance $\left(1333 \mu \mathrm{E} \mathrm{m}{ }^{-2}\right.$ $\mathrm{s}^{-1}$ ) recorded in the NOW, despite a large difference in the latitude of the investigated sites (about $35^{\circ} \mathrm{N}$ for the Japanese coastal waters compared with 75 to $79^{\circ} \mathrm{N}$ for the NOW). However, the impact of the latitude on the incident irradiance at each site is somehow offset by the extent of both investigations over time, each one experiencing a maximum value at a different time of year.

\section{Light attenuation by DOC, POC and chl a concentrations in the NOW}

Downwelling irradiance as well as the $K_{d}(\lambda)$ varied greatly in the water column over the whole period (Table 1). The stepwise linear regression models calculated for the whole period, singled out POC as being the most influencing component on $K_{d}(\lambda)$ for wavelength $>320 \mathrm{~nm}$ (Table 2). Its influence increased with wavelength, accounting for $36(340 \mathrm{~nm}$ ) to $79 \%$ (400 to $700 \mathrm{~nm}$ ) of the variance of light attenuation (Table 2).

During the pre-bloom period, spanning from 9 April to 12 May 1998, the NOW was almost entirely covered by sea-ice on the Canadian side, while ice melting started at the end of April on the Greenland side (Mundy \& Barber 2001). No significant relationship was found between $K_{d}(\lambda)$ and either POC or DOC con- centrations (Table 3). On the other hand, significant inverse relationships were found between $\mathrm{chl} a$ and $K_{d}(\lambda)$ (Table 3 ). These unexpected inverse relationships between chl $a$ and $K_{d}(\lambda)$ likely reveal a spatial pattern (Fig. 4), which exhibited higher $K_{d}(\lambda)$ values that corresponded to the stations located on the Canadian sides of the NOW. Conversely, lower $K_{d}(\lambda)$ values occurred at stations located on the Greenland side.

Indeed, the fact that $K_{d}(\lambda)$ values were higher on the Canadian than on the Greenland side (Mei et al. 2002) could have been due to the distinctive hydrodynamic regime of the NOW as reported by Lewis et al. (1996). For instance, the intrusion in the polynya of the West Greenland Current (WGC), flowing between the Carey Islands and Greenland coast, supplies warm and saline waters progressively mixing with the cold and less saline inflow from the Arctic Ocean flowing southward through the Smith Sound (Sadler 1976). Consequently, the northern and western parts of the NOW are characterized by Arctic waters, whereas the eastern part is characterized by Atlantic waters brought in by the WGC. This pattern was also outlined by Mostajir et al. (2001) throughout the NOW during the 1999 postbloom period on the basis of temperature-salinity characteristics of surface water. All these studies suggest that the eastern and western stations were under the influence of Atlantic and Arctic waters, respectively, even during the pre-bloom period.

Scully \& Miller (2000) reported that, for the same period and stations, absorptivity of colored dissolved organic matter $\left(a_{\mathrm{CDOM}}\right)$, measured at $310 \mathrm{~nm}$, was significant in the NOW, ranging from $>0.3$ to $<0.8 \mathrm{~m}^{-1}$. The $a_{\text {CDOM }}$ was generally low, varying between $>0.3$ and $<0.5 \mathrm{~m}^{-1}$ at stations located in the southeastern part of the NOW, and increased (ranging between $>0.5$ and $<0.8 \mathrm{~m}^{-1}$ ) towards the west and north. The average $a_{\mathrm{CDOM}}$ in the NOW during the pre-bloom was approximately $0.45 \mathrm{~m}^{-1}$ at $310 \mathrm{~nm}$ and seemed to contribute strongly $(\sim 70 \%)$ to the total attenuation during this period since the mean $K_{d}(\lambda)$ was then 0.68 and $0.59 \mathrm{~m}^{-1}$ at 305 and $313 \mathrm{~nm}$, respectively. Scully \& Miller (2000) concluded that the high $a_{\mathrm{CDOM}}$ values in the northeastern part result from the input of CDOM from the Arctic Ocean. Thus, during the pre-bloom period, the spatial pattern of $K_{d}(\lambda)$ in the NOW likely reflects the $a_{\mathrm{CDOM}}$ distribution patterns rather than those of chl $a$, POC and DOC.

Phytoplankton and DOC are usually considered as potentially important factors contributing to UVR attenuation (Baker \& Smith 1982, Kirk 1994). In the NOW, however, chl a data provided no evidence that phytoplankton had a greater effect than POC concentration on UVR penetration, and the same conclusion applied to DOC (Tables $2 \& 3$ ). During the bloom and postbloom periods, POC contributed mostly to the $K_{d}(\lambda)$ 
(Tables 2 \& 3) due to its high concentration (59.4 to $729.2 \mu \mathrm{g} \mathrm{C}^{-1}$ ). However, it has to be noted that during the bloom period, chl a was strongly correlated with POC $\left(\mathrm{R}^{2}=0.86, \mathrm{n}=11\right)$ and it was, therefore, difficult to determine their respective contributions to the $K_{d}(\lambda)$. During the post-bloom period, however, chl a was not significantly correlated with POC $\left(\mathrm{R}^{2}=0.34, \mathrm{n}=16\right)$.

In the Estuary and Gulf of St. Lawrence (Canada), Kuhn et al. (1999) reported a strong correlation between DOC and UVBR attenuation. They concluded that for all wavelengths in the UVR range, DOC was highly correlated with $K_{d}(\lambda)$ compared to chl $a$, which ranged from 0.05 to $2.02 \mu \mathrm{g} \mathrm{l}^{-1}$. However, the significant autocorrelation between DOC and chl $a$ in their data set made it difficult to determine their respective contributions to $K_{d}(\lambda)$. Nevertheless, their DOC concentrations, ranging from 0.45 to $3.59 \mathrm{mg} \mathrm{l}^{-1}$, were significantly higher than those found in the NOW. This major difference in terms of DOC concentrations would account for the distinct role played by the biooptical factors at these 2 sites. In temperate waters of Japan, Kuwahara et al. (2000) reported that UVR penetration was clearly controlled by the variability of biooptical factors such as chl a (ranging from $<1$ to $>8 \mu \mathrm{g}$ $\mathrm{l}^{-1}$ ), POC (15 to $80 \mu \mathrm{g} \mathrm{C}^{-1}$ ) and DOC (1.2 to $3 \mathrm{mg} \mathrm{C}^{-1}$ ). In particular, they demonstrated that $a_{\mathrm{CDOM}}$ was the major, year-round, UVR absorbing component, except in June, coinciding with the bloom conditions. During this period, particulate fraction was clearly the major light absorbing component due to the high contribution of pigments $\left(a_{\mathrm{PH}}\right)$ exceeding that of $a_{\mathrm{CDOM}}$. POC was the main contributing factor during the bloom period in the Japanese coastal waters and in the NOW. The difference observed in the conclusions for the post-bloom period can reasonably be attributed to the higher POC concentration in the NOW than in the Japanese waters. In Lake Erie, Smith et al. (1999) reported that particulate material contributed the most to UVR attenuation, even though the DOC concentrations in Lake Erie, ranging from 2.3 to $6.3 \mathrm{mg} \mathrm{C}^{-1}$, were higher than in the NOW. However, comparisons with our study are limited, for these authors considered total suspended solids (TSS) instead of POC.

A number of studies have shown that DOC is primarily responsible for UVR attenuation in marine environments (Kuhn et al. 1999, Kuwahara et al. 2000) and freshwaters (Morris et al. 1995, Laurion et al. 1997). The investigation conducted in the NOW, however, indicated that POC can also be the main contributor to $K_{d}(\lambda)$. It should be noted that not all authors use the same set of bio-optical factors as those in the present study (DOC, POC, chl a). For instance, Kuwahara et al. (2000) used pigment absorption $\left(a_{\mathrm{PH}}\right)$ and Smith et al. (1999) referred to TSS. Despite a lack of standardization, it turns out that the type of major contributing factor to light attenuation highly depends on the period studied and on the relative values and intrinsic variability of the measured bio-optical factors. In addition, the quality of DOC in marine waters, in particular the relative importance in CDOM, may add to this complexity. Indeed, humic substances in marine waters generally make up a smaller percentage of the bulk DOC ( 5 to $25 \%$ ) than in freshwater environments (40 to $80 \%$; Thurman 1985). The high aromaticity of humic substances makes them particularly susceptible to absorption of UV light as well as photochemically more reactive than other fraction of the DOC. However, little is known about the origin and distribution of marine humic substances. Flux estimates for the Arctic Ocean of terrestrially derived DOM suggest that the Canadian Arctic Archipelago may receive allochthonous DOM from Arctic rivers. Moreover, in the Arctic environment, the contribution of terrestrial DOM is probably small compared to other environments and anthropogenic sources can be excluded (Lara et al. 1993). Hence, the low aromaticity and concentrations of DOC in the NOW could be an explanation for the lack of relationship between dissolved matter and $K_{d}(\lambda)$.

In conclusion, the NOW exhibited low DOC concentrations and high temporal variability in particulate fraction concentrations. During the pre-bloom period, the absorption of CDOM likely prevailed, while during bloom and post-bloom periods POC was the major contributing factor to the total light attenuation. As shown by the present study, investigating seasonal successions of light attenuation together with hydrographic conditions allows the relative importance of bio-optical factors (chl $a$, POC and DOC) to be determined on an annual basis. Such a conclusion is in agreement with the work of Kuwahara et al. (2000).

\section{Relation between UVB attenuation and the depth of the SCM}

Vertical profiles of chl a concentration are routinely investigated since they give clues on the processes determining the vertical distribution of phytoplankton and consequently, lead to a better understanding of the dynamics of the pelagic ecosystem (Berman 1972, Kiefer et al. 1972, Cullen \& Eppley 1981, Cullen 1982). Throughout the survey, the NOW exhibited a great variability in: (1) the downwelling irradiance, $\operatorname{Ed}^{-}(\lambda)$ at the sea surface; and (2) the mean irradiance, $I(\lambda)$, in the euphotic zone as well as in the mixed layer. In the course of the bloom period, phytoplankton biomass and production reached high values of $19.8 \mathrm{mg} \mathrm{chl} \mathrm{a}$ $\mathrm{m}^{-3}$ and $2468 \mathrm{mg} \mathrm{C} \mathrm{m}^{-2} \mathrm{~d}^{-1}$, respectively (Klein et al. 2002). The high chl a concentration in the water column (Fig. 2) resulted from a combination of high $\mathrm{I}(\lambda)$, 
low $Z_{\mathrm{m}}$ and a high $Z_{\text {eu }} / Z_{\mathrm{m}}$ ratio (Tables $1 \& 4$ ). With increasing stratification and irradiance, a SCM developed in the water column (Table 4). Since the discovery of the phytoplankton heterogeneity with depth (Steele \& Yentsch 1960), considerable efforts have been dedicated to understanding the origin of SCM formation. Several explanations have been proposed, such as decreasing sinking rates at the pycnocline (Steele \& Yentsch 1960), aggregation (Cullen 1982), occurrence of a nitracline (Vandevelde et al. 1987) and maximum vertical stability (Loftus \& Seliger 1975). However, the location of the SCM is not always accounted for by these arguments (Sommaruga \& Psenner 1997).

In a Canadian lake, Xenopoulos et al. (2000) showed that under strong stratification conditions, an increase in incident UVBR enhanced its effect on phytoplankton. Both surface and $1 \mathrm{~m}$ depth chl a concentrations decreased when UVBR increased, despite the calculated UVBR penetration depth being only $0.21 \mathrm{~m}$. Meanwhile, an increase in phytoplankton biomass was observed at 2 and $3 \mathrm{~m}$, due to the migration of mainly flagellates and dinoflagellates towards these depths in response to this UVBR stress. This is in agreement with the work of Shilo (1982) who showed that flagella motility in the water column was driven by phototacticity or photophobicity, which correspond respectively to activation or inhibition of the movement by light conditions. In the present study, stations with $Z_{\mathrm{m}}<15 \mathrm{~m}$ exhibited a significant inverse relationship between $K_{d}(\lambda)$ and the depth of the SCM (Table 5), leading to deeper SCM with more UVR penetration relative to other situations. This relationship with the position of the SCM occurs in addition to that of PAR, as demonstrated by several authors (Cullen \& Eppley 1981, Banse 1987, Falkowski \& Raven 1997).

Lovejoy et al. (2002) found abundant dinoflagellates during the NOW 1998 cruise, making up to $47 \%$ of the total biomass in May 1998. Additionally, dinoflagellate abundance increased with depth. Floral involvement showed that mixotrophic dinoflagellates (mostly Gymnodinoids) were at least as abundant as heterotrophic during the bloom period (C. Lovejoy pers. comm.). This is consistent with other observations in both Arctic and Antarctic regions (Demers et al. 1986, Helbling et al. 1992, Booth \& Smith 1997) showing that dinoflagellates are more abundant in highly stratified waters, as was the case during the bloom period in the NOW. Among the mobile organisms, dinoflagellates present one of the highest surface/volume ratios making them more susceptible to UVR than larger species (Karentz et al. 1991, Garcia-Pichel 1996). Accordingly, flagellates have been shown to be UVR reactive (Vincent \& Roy 1993, Helbling et al. 1994). Thus, the relationship between $K_{d}(\lambda)$ in the UVR range and the depth of the SCM could be a consequence of cell migration below the depth of UVR penetration depth where they are protected from UVR-induced physiological damages. Similar results have been reported by Sommaruga \& Psenner (1997) for a high mountain lake in the Austrian Alps. These authors concluded that the old controversy on whether high irradiance levels or nutrient limitation is responsible for the deep phytoplankton maximum in high mountain lakes may now be seen in a new (UV) light. To our knowledge, this is the first time that the depth of the chlorophyll maximum has been found to be related to UV light in marine waters. Considering the results of the present investigation and the possible increase in the UVR/PAR ratio at Earth's surface in coming years, future studies should take into account the influence of UVR on the vertical distribution of phytoplanktonic communities in highly stratified waters.

Acknowledgements. This work was funded by a National Sciences and Engineering Research Council of Canada (NSERC) grant and by the Fonds FCAR of Québec to S.D. We would like to acknowledge C. Belzile, I. Laurion and S. Roy for field measurements and analyses of light data. We also thank L. Legendre, M. Gosselin, K. Cochran, D. Amiel, P. Yager, L. Miller, B. LeBlanc, Z.-P. Mei and R. Beret for sampling and analyses of chl $a$, POC and DOC data. Special thanks go to Y. Gratton for $Z_{\mathrm{m}}$ calculations. The authors greatly appreciated the availability of Louis Fortier, Martin Fortier and the crew onboard the CCGS 'Pierre Radisson'. For English language correction, we thank Huxiang Xie. The authors thank the 3 anonymous reviewers for valuable comments on the manuscript. This study is a contribution to the research programs of the International North Water Polynya Study and to the Institut des sciences de la mer de Rimouski. This manuscript is a part of the $\mathrm{PhD}$ of $\mathrm{C} . \mathrm{V}$., who received financial support from the Ministère des Relations Internationales du Québec (Canada), the Ministère de l'Éducation Nationale and the Ministère de la Recherche et de la Technologie (France).

\section{LITERATURE CITED}

Austin J, Butchart N, Shine KP (1992) Possibility of an Arctic ozone hole in a doubled- $\mathrm{CO}_{2}$ climate. Nature 360:221-222

Bâcle J, Carmack EC, Ingram RG (2002) Water column structure and circulation under the North Water during transition: April-July 1998. Deep-Sea Res Part II 49:4907-4925

Baker KS, Smith RC (1982) Bio-optical classification and model of natural waters 2. Limnol Oceanogr 27:500-509

Banse K (1987) Clouds, deep chlorophyll maxima and the nutrient supply to the mixed layer of stratified water bodies. J Plankton Res 9:1031-1036

Belzile C, Johannessen S, Gosselin M, Demers S, Miller WL (2000) UV attenuation by dissolved and particulate constituents of first-year ice during late spring in an Arctic polynya. Limnol Oceanogr 45:1265-1273

Belzile C, Vincent WF, Gibson JAE, Van Hove P (2001) Biooptical characteristics of the snow, ice, and water column of a perennially ice-covered lake in the High Arctic. Can J Fish Aquat Sci 58:2405-2418

Berman T (1972) Profiles of chlorophyll concentrations by in vivo fluorescence: some limnological applications. Limnol Oceanogr 17:616-618 
Boelen P, Obernosterer I, Vink AA, Buma AGJ (1999) Attenuation of biologically effective UV radiation in tropical Atlantic waters measured with a biochemical DNA dosimeter. Photochem Photobiol 69:34-40

Booth BC, Smith WO Jr (1997) Autotrophic flagellates and diatoms in the Northeast Water Polynya, Greenland: summer 1993. J Mar Syst 10:241-261

Bruce EJ, Handley PL, Wan Z, Smith RC (1994) Estimation of ozone concentrations based on measurements of solar ultraviolet radiation in the Antarctic using the BSI PUV510 instrument. SPIE Ocean Optics 2258:12-20

Chatila K, Demers S, Mostajir B, Gosselin M, Chanut JP, Monfort P (1999) Bacterivory of a natural heterotrophic protozoan community exposed to different intensities of ultraviolet-B radiation. Aquat Microb Ecol 20:59-74

Chipperfield M (1991) Stratospheric ozone depletion over the Arctic. Nature 349:279-280

Cullen JJ (1982) The deep chlorophyll maximum: comparing vertical profiles of chlorophyll a. Can J Fish Aquat Sci 39: 791-803

Cullen JJ, Eppley RW (1981) Chlorophyll maximum layers of the Southern California Bight and possible mechanisms of their formation and maintenance. Oceanol Acta $4: 23-32$

Demers S, Legendre L, Theriault JC (1986) Phytoplankton responses to vertical tidal mixing. In: Bowman J, Yentsch M, Peterson WT (eds) Lecture notes on coastal and estuarine studies. Springer-Verlag, Berlin, p 1-40

Falkowski PG, Raven JA (1997) Aquatic photosynthesis. Blackwell Science, Oxford

Farman JC, Gardiner BG, Shanklin JD (1985) Large losses of total ozone in Antarctica reveal seasonal ClOx/NOX interaction. Nature 328:207-210

Fauchot J, Gosselin M, Levasseur M, Mostajir B, Belzile C, Demers S, Roy S, Villegas PZ (2000) Influence of UV-B radiation on nitrogen utilization by a natural assemblage of phytoplankton. J Phycol 36:484-496

Ferreyra GS, Demers S, Del Giorgio P, Chanut JP (1997) Responses of phytoplankton productivity and community structure to UV radiation in the Redberry Lake. Can J Fish Aquat Sci 54:705-714

Garcia-Pichel F (1996) The absorption of ultraviolet radiation by microalgae: simple optics and photobiological implications. Sci Mar 60:73-79

Helbling EW, Villafañe V, Ferrario M, Holm-Hansen O (1992) Impact of natural ultraviolet radiation on rates of photosynthesis and specific marine phytoplankton species. Mar Ecol Prog Ser 80:89-102

Helbling EW, Villafañe V, Holm-Hansen O (1994) Effects of ultraviolet radiation on Antarctic marine phytoplankton photosynthesis with particular attention to the influence of mixing. In: Weiler CS, Penhale PA (eds) Ultraviolet radiation in Antarctica: measurements and biological effects. American Geophysical Union, Washington, DC, p 207-227

Herndl G, Müller-Niklas JG, Frick J (1993) Major role of ultraviolet-B in controlling bacterioplankton growth in the surface layer of the ocean. Nature 361:717-719

Hofmann DJ, Deshler T (1991) Evidence from balloon measurements for chemical depletion of stratospheric ozone in the Arctic winter of 1989-90. Nature 349:300-305

Holm-Hansen O, Lorenzen CJ, Holmes RW, Strickland JDH (1965) Fluorometric determination of chlorophyll. J Cons Perm Int Explor Mer 30:1-15

Jokiel PL, York RH (1984) Importance of ultraviolet radiation in photoinhibition of microalgal growth. Limnol Oceanogr 29:192-199

Karentz D, Cleaver JE, Mitchell DL (1991) Cell survival char- acteristics and molecular responses of Antarctic phytoplankton to ultraviolet-B radiation. J Phycol 27:326-341

Kiefer DA, Holm-Hansen O, Goldman CR, Richards R Berman T (1972) Phytoplankton in lake Tahoe: deepliving populations. Limnol Oceanogr 17:418-422

Kirk JTO (1994) Light and photosynthesis in aquatic ecosystems. Cambridge University Press, Cambridge

Klein B, LeBlanc B, Mei Z, Michaud RB and 11 others (2002) Size-fractionated phytoplankton and primary production in the North Water Polynya. Deep-Sea Res Part II 49:4983-5002

Knap A, Michaels A, Close A, Duclow H, Dickson A (1996) Protocols for the Joint Global Ocean Flux Study (JGOFS) core measurements. Report No. 19. UNESCO, Paris

Kuhn P, Browman H, McArthur B, St-Pierre JF (1999) Penetration of ultraviolet radiation in the waters of the estuary and Gulf of St. Lawrence. Limnol Oceanogr 44:710-716

Kuwahara VS, Ogawa H, Toda T, Kikuchi T, Taguchi S (2000) Variability of bio-optical factors influencing the seasonal attenuation of ultraviolet radiation in temperate coastal waters of Japan. Photochem Photobiol 72:193-199

Lara RJ, Hubberten U, Kattner G (1993) Contribution of humic substances to the dissolved nitrogen pool in the Greenland Sea. Mar Chem 41:327-336

Laurion I, Vincent WF, Lean DRS (1997) Underwater ultraviolet radiation: development of spectral models for northern high latitudes lakes. Photochem Photobiol 65:107-114

Lewis EL, Ponton D, Legendre L, Leblanc B (1996) Springtime sensible heat, nutrients and phytoplankton in the North Water Polynya, Canadian Arctic. Cont Shelf Res 16: 1775-1792

Loftus ME, Seliger HH (1975) Some limitations of the in vivo fluorescence technique. Chesapeake Sci 16:79-92

Lovejoy C, Legendre L, Martineau MJ, Bâcle J, von Quillfeldt CH (2002) Distribution of phytoplankton and other protists in the North Water. Deep-Sea Res Part II 49:5027-5048

MacIntyre HL, Cullen JJ (1996) Primary production by suspended and benthic microalgae in a turbid estuary: timescales of variability in San Antonio Bay, Texas. Mar Ecol Prog Ser 145:245-268

Markager S, Vincent WF (2000) Spectral light attenuation and the absorption of $\mathrm{UV}$ and blue light in natural waters. Limnol Oceanogr 45:642-650

Mei ZP, Legendre L, Gratton Y, Tremblay JE and 8 others (2002) Physical control of spring-summer phytoplankton dynamics in the North Water, April-July 1998. Deep-Sea Res Part II 49:4959-4982

Miller LA, Yager PL, Erickson KA, Amiel D and 8 others (2002) Carbon distributions and fluxes in the North Water Polynya, 1998 and 1999. Deep-Sea Res Part II 49: 5151-5170

Morris DP, Zagarese $\mathrm{H}$, Williamson CE, Balseiro EG, Hargreaves BR, Modenutti B, Moeller R, Queimalinos C (1995) The attenuation of solar UV radiation in lakes and the role of dissolved organic carbon. Limnol Oceanogr 40: 1381-1391

Mostajir B, Demers S, De Mora S, Belzile C and 9 others (1999) Experimental test of the effect of ultraviolet-B radiation in a planktonic community. Limnol Oceanogr 44: 586-596

Mostajir B, Gosselin M, Gratton Y, Booth B and 5 others (2001) Surface water distribution of pico- and nanophytoplankton in relation to 2 distinctive water masses in the North Water, northern Baffin Bay, during fall. Aquat Microb Ecol 23:205-212

Muench RD (1971) The physical oceanography of the northern Baffin Bay Region. In the Baffin Bay-Northwater Pro- 
ject Science Report No. 1. Arctic Institute of North America, Washington, DC

Mundy CJ, Barber DG (2001) On the relationship between the spatial and temporal evolution of sea ice patterns and the physical mechanisms creating and maintaining the NOW Polynya. Atmos Ocean 39:327-341

Parsons TR, Maita Y, Lalli CM (1984) A manual of chemical and biological methods for seawater analysis. Pergamon Press, Toronto

Ramanathan V (1988) The greenhouse theory of climate change: a test by an inadvertent global experiment. Science 240:293-299

Rex M, Harris NRP, Von Der Gathen P, Lehmann R and 20 others (1997) Prolonged stratospheric ozone loss in the 1995-96 Arctic winter. Nature 389:835-838

Rodriguez CA, Browman HI, Runge JA, St-Pierre JF (2000) Impact of solar ultraviolet radiation on hatching of a marine copepod, Calanus Finmarchicus. Mar Ecol Prog Ser 193:85-93

Sadler HE (1976) Water, heat, and salt transports through Nares Strait, Ellesmere Island. J Fish Res Board Can 33: $2286-2295$

Schneider N, Müller P (1990) The meridional and seasonal structures of the mixed-layer depth and its diurnal amplitude during the Hawaii-to-Tahiti Shuttle Experiment. J Phys Oceanogr 20:1395-1404

Scully NM, Miller WL (2000) Spatial and temporal dynamics of colored dissolved organic matter in the North Water Polynya. Geophys Res Lett 27:1009-1011

Shilo M (1982) Photosynthetic microbial communities in aquatic ecosystems. Phil Trans R Soc Lon B 297:565-574

Shindell DT, Rind D, Lonergan P (1998) Increased polar stratospheric ozone losses and delayed eventual recovery owing to increasing greenhouse-gas concentrations. Nature 392:589-592

Smith REH, Furgal JA, Charlton MN, Greenberg BM, Hiriart V, Marwood C (1999) Attenuation of ultraviolet radiation in a large lake with low dissolved organic matter concentrations. Can J Fish Aquat Sci 56:1351-1361

Solomon S (1990) Progress towards a quantitative understanding of Antarctic ozone depletion. Nature 347:347-354

Editorial responsibility: Otto Kinne (Editor),

Oldendorf/Luhe, Germany
Sommaruga R, Psenner R (1997) Ultraviolet radiation in a high mountain lake of the Austrian Alps: air and underwater measurements. Photochem Photobiol 65:957-963

Steele JH, Yentsch CS (1960) The vertical distribution of chlorophyll. J Mar Biol Assoc UK 39:217-226

Stirling I (1997) The importance of polynyas, ice edges and leads to marine mammals and birds. J Mar Syst 10:9-21

Struzik E (1989) Arctic oases. Equinox 48:38-49

Tarasick DW, Fioletov VE (1997) The distribution of ozone and ozone-depleting substances in the atmosphere and observed changes. In: Wardle DI, Kerr JB, McElroy CT, Francis DR (eds) Ozone science: a Canadian perspective on the changing ozone layer. Environment Canada, Ottawa, p 15-40

Thurman EM (1985) Aquatic humic substances. In: Thurman EM (ed) Organic geochemistry of natural waters. Nijhoff M \& Junk W, Boston, p 273-361

Tremblay JE, Gratton Y, Fauchot J, Price NM (2002) Climatic and oceanic forcing of new, net, and diatom production in the North Water. Deep-Sea Res Part II 49:4927-4946

UNESCO (1983) Algorithms for computation of fundamental properties of sea water. UNESCO Tech Pap Mar Sci 44:53

Vandevelde T, Legendre L, Therriault JC, Demers S, Bah A (1987) Subsurface chlorophyll maximum and hydrodynamics of the water column. J Mar Res 45:377-396

Vincent WF, Roy S (1993) Solar ultraviolet-B radiation and aquatic primary production damage, protection, and recovery. Environ Rev 1:1-12

Wickham S, Carstens M (1998) Effects of ultraviolet-B radiation on 2 arctic microbial food webs. Aquat Microb Ecol 16:163-171

Xenopoulos MA, Prairie YT, Bird DF (2000) Influence of ultraviolet-B radiation, stratospheric ozone variability, and thermal stratification on the phytoplankton biomass dynamics in a mesohumic lake. Can J Fish Aquat Sci 57 600-609

Zagarese HE, Williamson CE (2000) Impact of solar UV radiation on zooplankton and fish. In: de Mora S, Demers S, Vernet $M$ (eds) The effects of UV radiation in the marine environment. Cambridge University Press, Cambridge, p 279-309

Submitted: March 26, 2002; Accepted: January 13, 2003

Proofs received from author(s): April 3, 2003 